\title{
AN EXPERIMENTAL INVESTIGATION ON BEHAVIOUR OF GEO- POLYMER CONCRETE SLAB WITH FLY-ASH \& GGBS UNDER AMBIENT CURING
}

\author{
Praveen Mathapati ${ }^{1}$, Ramesh Babu ${ }^{2}$, M.U.Aswath ${ }^{3}$ \\ ${ }^{I}$ M.Tech Student, Department of Civil Engineering, Bangalore Institute of Technology, Karnataka, India. \\ ${ }^{2}$ Assistant Professor, Department of Civil Engineering, Bangalore Institute of Technology, Karnataka, India. \\ ${ }^{3}$ Professor \& HOD, Department of Civil Engineering, Bangalore Institute of Technology, Karnataka, India.
}

\begin{abstract}
GeoPolymer Concrete (GPC) is an eco-friendly binding alternative material for an Ordinary Portland Concrete (OPC). Geopolymer concrete is produced by mixing the GGBS, flyash, alkaline activator solution, fine aggregate, coarse aggregate. Alkaline solution is composed of Sodium Silicate $\left(\mathrm{Na}_{2} \mathrm{SiO}_{3}\right)$ and Sodium hydroxide ( $\left.\mathrm{NaOH}\right)$. This research work deals with an experimental investigation on behavior of geopolymer concrete slab with flyash \& GGBS under ambient curing. In this project work the behavior of the slab with normal conventional concrete and geopolymer concrete slabs has been studied in detail. The overall dimensions of the slabs are $1000 \mathrm{~mm} X 1000 \mathrm{~mm} X 60 \mathrm{~mm}$ and reinforced with the $8 \mathrm{~mm}$ HYSD bars at $230 \mathrm{~mm} \mathrm{c} / \mathrm{c}$ are casted. For the geopolymer concrete slabs of $25 \%$ of GGBS $75 \%$ of flyash is used as a binding material for OPC. The $16 \mathrm{M}$ molarity of the $\mathrm{NaOH}$ solution used. The following tests conducted on GPC \& M-20 concrete Compressive Strength, Split Tensile Strength, Flexural Strength. and The following analysis is conducted on the slab Cracks developed due to loading, Shear failure, Failure due to ultimate load, Cracks pattern due to ultimate load, Deflection due to loading, Load v/s deflection graph.
\end{abstract}

Keywords: GeoPolymer, Molarity, Sodium hydroxide, Sodium Silicate, Flyash, GGBS.

\section{INTRODUCTION}

Concrete is a synonymous material with the longevity and strength. It has emerged as a one of the dominant construction material for the infrastructure development of the twenty - first century. Along with this, durable concrete can be easily manufactured and can be fabricated from readily available constituents. Hence it can be used for all types of structural systems. The challenge for the civil engineering community in the future is to analyze the project in the harmony with the concept of sustainable development of the community. This involves the use of the high performance materials and the materials can be manufactured at the low cost and lowest possible environmental impact.

In 1978 "Davidovits" of France first introduced the term "geo polymer" to the world; this became new field of research and developing technology. The use of the fly ash and the GGBS in the normal concrete has revolutionized the construction industry, by economizing the construction cost and decreasing the ash content. In this paper an experimental investigation conducted on behavior of geo polymer concrete slab with fly-ash \& GGBS under ambient curing. In case of the geo polymer concrete cement is fully replaced by the fly-ash and GGBS in the proportion of $75 \%$ and $25 \%$ respectively as these both are actually containing silica - alumina containing materials. Hence these can be used as source materials for the generation of the geo polymer concrete. This will solves two problems simultaneously viz. saving the costly cement and the bulk utilization of the industrial waste fly-ash and GGBS. A Geo polymer concrete is an inorganic polymer composite, with ability to produce environmentally sustainable construction by supplementing or replacing the conventional ordinary portland cement concretes.

\section{LITERATURE REVIEW}

1. T Kiran et al. (2015) ${ }^{[1]}$ studied "Impact test on geo polymer concrete slabs" This paper deals with the study of impact resistance capacity of geopolymer concrete slabs subjected to impact loading. For this study, ten specimens of size $0.6 \mathrm{mX} 0.6 \mathrm{mX} 0.06 \mathrm{~m}$ were casted with 9 different combination of geopolymer concrete mix using different molar $\mathrm{NaOH}$ solutions and different percentages of mineral admixtures and normal concrete slab as control slab. The molarity of $\mathrm{NaOH}$ solution used was $8 \mathrm{M}, 12 \mathrm{M}$ and $16 \mathrm{M}$. Fly ash and GGBS admixtures were used in three different ratios of 100:0, 75:25 and 50:50. These slabs were oven dried at $60^{\circ} \mathrm{C}$ for about 24 hours. All these slabs were subjected to impact loading by the drop weight test method having a drop weight of $75.50 \mathrm{~N}$ from a height of $700 \mathrm{~mm}$. From this study they have concluded that with the increase in the concentrations of the molarity of the sodium hydroxide the strength characteristics and impact resistance capacity of the geo polymer concrete specimen increases.

2. Dr.Manjunatha $\mathbf{N}$ Hegde et al. (2014) ${ }^{[2]}$ In this paper author studied the effects of flexural strength in between the uncarbonated and carbonated slabs of different durations and to determine the depth of carbonation among carbonated slabs. This experiment consisted of 16 slabs which included 
4 series (each series having 2 specimens with 10 and $20 \mathrm{~mm}$ cover to reinforcement). Each slab is of size $1000 \times 500 \times 75 \mathrm{~mm}$ and reinforced with $6 \mathrm{~mm}$ MS bars at $230 \mathrm{~mm} \mathrm{c} / \mathrm{c}$ at bottom in Both directions First series consisted of control specimens and the other 3 series consisted of slabs subjected to 48,96 and 144 hours of duration of carbonation. For casting of slabs M40 mix proportions of geo polymer concrete consisting of GGBS, flyash, alkaline solution i.e. sodium hydroxide $(\mathrm{NaOH})$ and sodium silicate $\left(\mathrm{Na}_{2} \mathrm{SiO}_{3}\right)$, manufactured sand, coarse aggregate, water and superplasticizer. Series of slabs were kept in the carbonation chamber for the specified time periods and tested for flexure over span/4 from supports with two sides are simply supported and the line loads is applied on it.

3. Madheswaran C K et al. (2014) ${ }^{[3]}$ In this paper author studied "Investigation on behaviour of reinforced geopolymer concrete slab under repeated low velocity impact loading", the reinforced GPC slabs with and without steel fibers and compare with that of OPCC slabs. The overall dimensions of the GPC slab are $1 \mathrm{mX} 1 \mathrm{mX} 60 \mathrm{~mm}$ Finite element modeling of slab was also carried out using ANSYS software. The Solid 65 element and link 8 elements were used to model the concrete slab and Reinforcement respectively. Displacement boundary conditions are applied at the supports. The measured impact load time history is used to excite the structure. Transient dynamic analysis was carried out. Results obtained in the form of the deflection time histories, the failure crack patterns for the fibre reinforced slabs and for the plain reinforced slabs predicted by the finite element analysis are compared with the results obtained from the experimental study.

4. Dr. Amarnath K. et al. (2015) ${ }^{[4]}$ Study on "Flexural Behavior of Fly Ash based Reinforced Rectangular Geopolymer Concrete Slabs", In this experimental work the flexural behavior of the rectangular geo polymer concrete slabs is studied by using flyash and GGBS as a binder material. The proportion flyash and GGBS used is $70 \%$ and $30 \%$ respectively. And the molarity of the Sodium hydroxide solution used is of $8 \mathrm{M}$. The ratio of the Sodium silicate to the sodium hydroxide solution is 2.5. Seven rectangular slabs were casted with the overall dimension of the slab as $1300 \mathrm{~mm} \times 650 \mathrm{~mm}$ with the $75 \mathrm{~mm}$ overall thickness with aspect ratio of 2.0. The reinforcement used for these slabs of Fe 500 High Yield Strength Deformed (HYSD) bars of $8 \mathrm{~mm}$ diameter were placed parallel to $1300 \mathrm{~mm}$ side and $8 \mathrm{~mm}$ dia. bars were placed parallel to the shorter sides are placed. All these slabs were tested under the 50T loading frame. For testing of the slabs support condition provided on all the sides is simply supported and the uniformly distributed load (UDL) is applied on the slab panels. The study of the load $\mathrm{v} / \mathrm{s}$ deflection is noted.

\section{MATERIALS AND METHODOLOGY}

\subsection{Ingredients of geo polymer concrete}

\subsubsection{Fly-ash}

Flyash is used a mineral admixture, The specific gravity of fly-ash is to be 2.25 and Fineness of the fly-ash which is determined from the Blaine's air permeability test is to be $325 \mathrm{~m}^{2} / \mathrm{kg}$. For this research work the "Class F" fly ash is used. This has been procured from the Ready Mix Concrete (RMC) - HIGH TECH plant Bangalore.

\subsubsection{Ground Granulated Blast Furnace Slag (GGBS)}

The specific gravity of is to be GGBS 2.85 and Fineness of the GGBS which is determined from the Blaine's air permeability test is to be $325 \mathrm{~m}^{2} / \mathrm{kg}$. For this research work the GGBS is also used as a source material. This has been procured from the Ready Mix Concrete (RMC) - INDIA plant Bangalore.

\subsubsection{Preparation of alkaline activator solution}

\subsubsection{Sodium Hydroxide Solution (SHS)}

Solid particles or pellets or granules of the sodium hydroxide flux will be mixed very slowly with water in several stages under fully ventilated conditions. Artificial cooling can be done by pre cooled water or by using fans.

\subsubsection{Sodium Silicate Solution (SSS)}

Sodium silicate solution (SSS) is measured by weight, because it is quite difficult to measure by volume. And this solution is highly viscous and specific gravity of the sodium silicate is of 1.6. This alkaline activator solution is a mixture of the sodium silicate solution and sodium hydroxide solution.

\subsubsection{Cement}

Type of cement used for this research work is OPC 43 Grade conforming to IS-8112, brand of cement is Zuari cement, specific gravity of the cement is 3.15 , initial setting time of the cement is $30 \mathrm{~min}$, and final setting time of the cement is $460 \mathrm{~min}$.

\subsubsection{Fine aggregate}

Good quality of river sand is used as a fine aggregate for this research work. Specific gravity of the fine aggregate is 2.50. Water absorption of fine aggregate is $1.2 \%$. Sieve analysis of fine aggregate carried out as per IS-383:1970. \& the fineness modulus of the fine aggregate is 2.81 .

\subsubsection{Coarse aggregate}

Good quality of crushed angular coarse aggregates is used for this research work. Specific gravity of the coarse aggregate is 2.70 . And water absorption of coarse aggregate is $0.6 \%$. Sieve analysis of the coarse aggregate as per IS $383: 1970 . \&$ the fineness modulus of the coarse aggregate is 3.90 .

\subsection{Design of geo polymer concrete mixes}

The conventional mix design procedure such as water cement ratio and water binder ratio cannot be used directly. Proportioning of the basic ingredients of geo polymer concretes needs systematic detailed experimental investigations; The wet density of geo polymer concrete is approximately $2400 \mathrm{Kg} / \mathrm{m}^{3}$. The ratio of Sodium Silicate $\left(\mathrm{Na}_{2} \mathrm{SiO}_{3}\right)$ to Sodium Hydroxide $(\mathrm{NaOH})$ is 2.5 . Total water 
Content 160 litre $/ \mathrm{m}^{3}$ (assumed) and aggregate content as $75 \%$ of total mix. Then assuming $62 \%$ of Coarse aggregates and Fine aggregates of $38 \%$. The water content in Sodium Silicate is $50 \%$ it is obtained from the chemical manufacturer. From the earlier research study it is found that $1000 \mathrm{gm}$ of $\mathrm{NaOH}$ solution contains $443 \mathrm{gm}$ of $\mathrm{NaOH}$ Pallets \& $557 \mathrm{gms}$ of water. Then $16 \mathrm{M}$ of sodium hydroxide solution can be obtained. Conventional M-20 concrete designed as per IS:10262-2009.

\subsection{Mixing}

When fresh geo polymer concrete is mixed it was cohesive and grey in color. The amount of water added to the geo polymer concrete mix plays a very important role. All ingredients of the geo polymer concrete calculated as per the mix design are weighed and mixing is done by using tilting drum mixer. Initially all these ingredients were mixed for three minutes (Dry mixing), after few minutes alkaline activator solutions is added slowly, these solutions were prepared 24hours prior to mixing. Slump value for M-20 concrete is $90 \mathrm{~mm}$ and that for the geo polymer concrete slump value is of $110 \mathrm{~mm}$.

\subsection{EXPERIMENTAL PROGRAM}

Table -1: Experimental program

\begin{tabular}{|l|c|c|c|c|}
\hline \multicolumn{1}{|c|}{ Specimen } & $\begin{array}{c}\text { Dimension in } \\
\text { mts }\end{array}$ & $\begin{array}{c}\text { M-20 } \\
\text { Concrete }\end{array}$ & GPC & Total \\
\hline Slab & $1 \times 1 \times 0.06$ & 3 & 3 & 6 \\
\hline Cubes & $0.15 \times 0.15 \times 0.15$ & 9 & 9 & 18 \\
\hline Cylinders & 0.15 Dia.X0.3 & 6 & 6 & 12 \\
\hline Beam (Prism) & $0.5 \times 0.1 \times 0.1$ & 3 & 3 & 6 \\
\hline
\end{tabular}

\subsection{CASTING OF CONCRETE SPECIMENS}

Cement, fine aggregate and coarse aggregate were taken in mix proportion 1: 2.25: 3.96 which correspond to M20 grade of concrete. In all the ingredients were dry mixed in a pan tilting drum mixer homogeneously. To this dry mix, required quantity of water is added of $(\mathrm{W} / \mathrm{C}=0.5) \&$ the entire mix was again homogenously mixed. And filled in the moulds, then the specimens were given smooth surface and taken out of the vibrating table. After the compaction, the specimens were given smooth finish surface. After 24 hours the specimen were demoulded and transferred to curing tank were in they were allowed to cure for 7 and 28 days, then they were tested for respective strengths i.e. compressive strength, tensile strength, flexural strength.

\subsubsection{Casting of Slabs}

The wooden moulds of size $1 \mathrm{mX} 1 \mathrm{mX} 0.06 \mathrm{~m}$ with these clear spacing's were prepared by using plywood boards. A non absorbent thin layer of polythene sheets is laid over the moulds. In order to provide the cover to the slabs cover blocks were used, these are provided at a spacing of $0.3 \mathrm{~m}$. These cover blocks laid in the bottom edges of the reinforcement is placed in required manner. Concrete is laid into the slab mould in 3 layers. Each layer is compacted by giving a manual stroke using rammer of weight $5 \mathrm{~kg}$ and it is compacted from a height of $0.5 \mathrm{~m}$ with 25 blows on each layer of the slab. Fig. shows casting of slabs.

\subsubsection{Curing}

In this research work GPC mix specimens are subjected to the self curing i.e. the curing is done in ambient temperature or room temperature
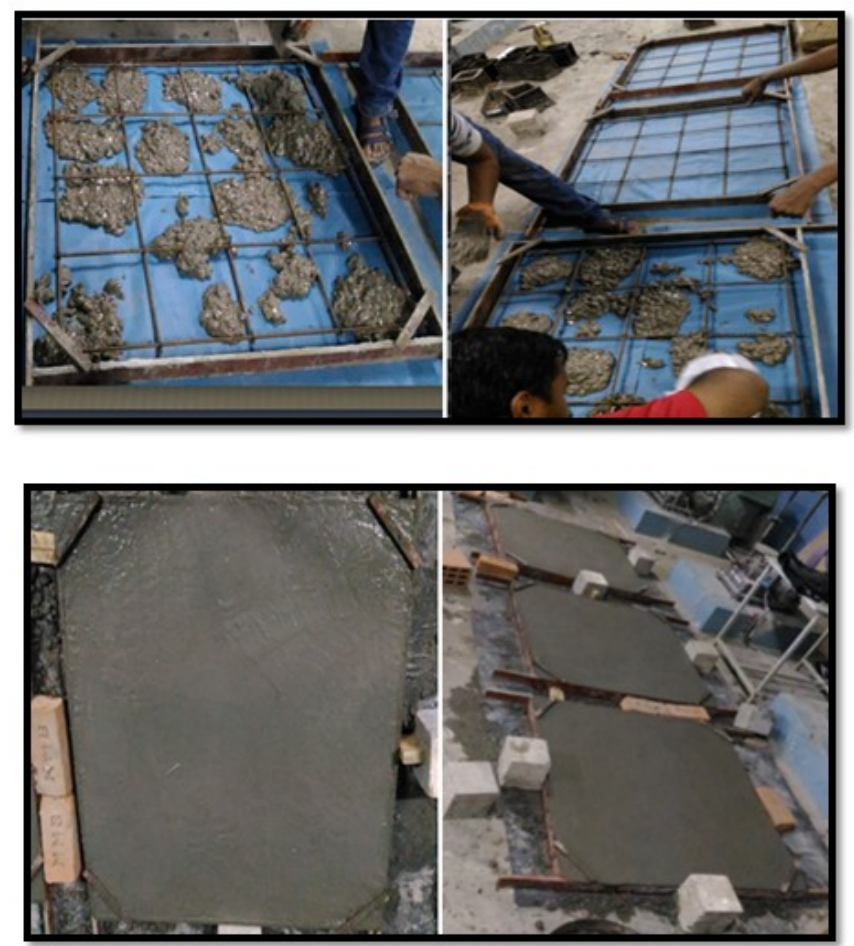

Fig -1: Casting of GPC \& M-20 concrete OPC Slabs

\subsection{TESTING OF CONCRETE SPECIMENS}

\subsubsection{Compressive strength test}

After 7, 28 and 56 days curing, the concrete cubes were tested on compression testing machine (CTM) as per I.S. 516-1959. The failure load was noted.

Table-2 Compressive strength results for 7, $28 \& 56$ days

\begin{tabular}{|c|c|c|c|}
\hline Specimen & $\begin{array}{c}\text { For 7 } \\
\text { days MPa }\end{array}$ & $\begin{array}{c}\text { For 28 } \\
\text { days MPa }\end{array}$ & $\begin{array}{c}\text { For 56 } \\
\text { days MPa }\end{array}$ \\
\hline $\begin{array}{c}\text { M-20 } \\
\text { concrete }\end{array}$ & $\mathbf{1 8 . 2 2}$ & $\mathbf{3 6 . 4 4}$ & $\mathbf{4 0 . 3}$ \\
\hline GPC & $\mathbf{4 4 . 1 5}$ & $\mathbf{6 3 . 7 1}$ & $\mathbf{7 0 . 2 2}$ \\
\hline
\end{tabular}

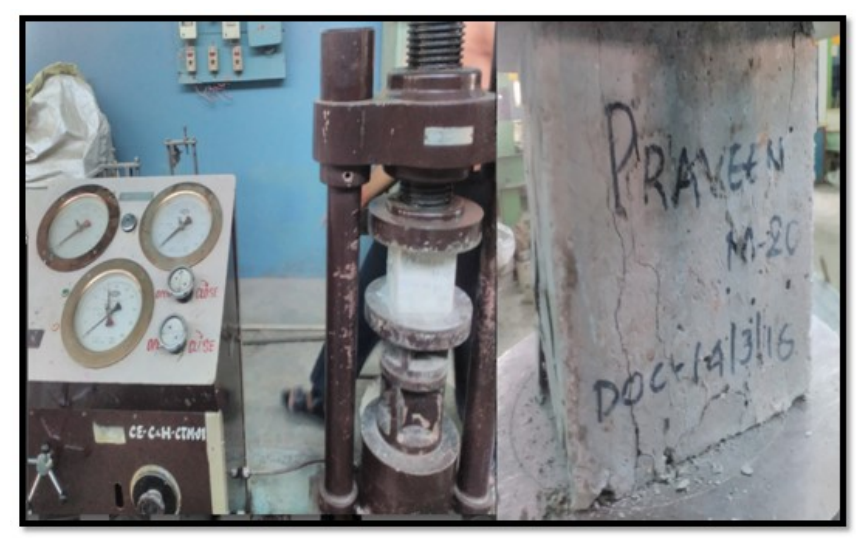

Fig -2: Compressive strength test 


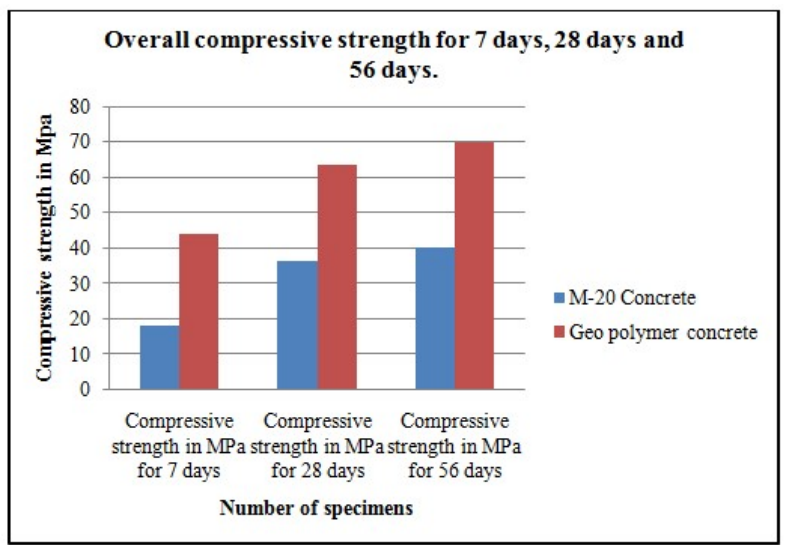

Chart -1: Overall compressive strength for 7 days, 28 days $\& 56$ days.

\subsubsection{Spilt tensile strength test}

After 7 and 28 days of curing the concrete cylinder specimens were tested under compression testing machine. The failure load was noted.

Table-3 Split tensile strength results for 7, 28 days

\begin{tabular}{|c|c|c|}
\hline Specimen & For 7 days MPa & For 28 days MPa \\
\hline M-20 concrete & $\mathbf{1 . 2 4}$ & $\mathbf{2 . 3 6}$ \\
\hline GPC & $\mathbf{1 . 9 7}$ & $\mathbf{3 . 4 1}$ \\
\hline
\end{tabular}

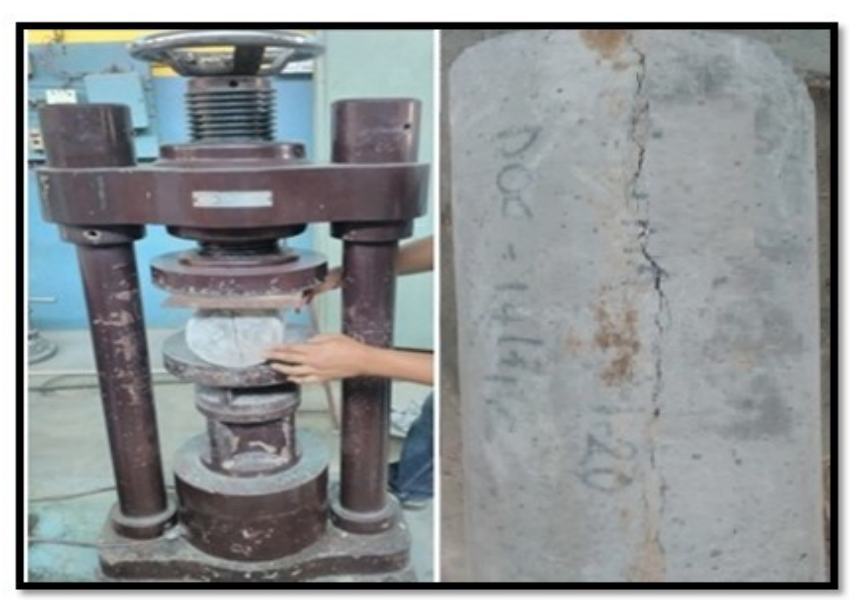

Fig -3: Split tensile strength test

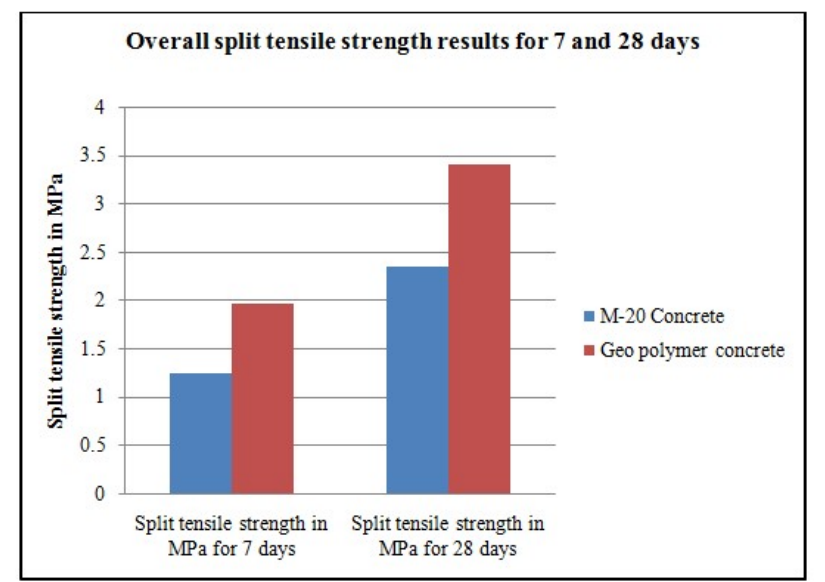

Chart -2: Split tensile strength results for 7 days, 28 days.

\subsubsection{Flexural Strength test}

After curing, the concrete prism specimens were tested according to IS: 516-1959. Modulus of rupture is measure of flexural strength and it can be calculated to the nearby 0.05 $\mathrm{MPa}$. Flexural strength of M-20 concrete \& GPC for 28 days in $\mathrm{MPa}$.

Table-4 Flexural strength results for 28 days

\begin{tabular}{|c|c|c|}
\hline Specimen & $\begin{array}{c}\text { M-20 Conc. } \\
\text { Strength in MPa }\end{array}$ & $\begin{array}{c}\text { GPC Strength in } \\
\mathrm{MPa}\end{array}$ \\
\hline 1 & $\mathbf{4 . 1 3}$ & $\mathbf{4 . 2 2}$ \\
\hline 2 & $\mathbf{4 . 1 0 4}$ & $\mathbf{4 . 2 4}$ \\
\hline 3 & $\mathbf{4 . 0 7 2}$ & $\mathbf{4 . 2 0 8}$ \\
\hline
\end{tabular}

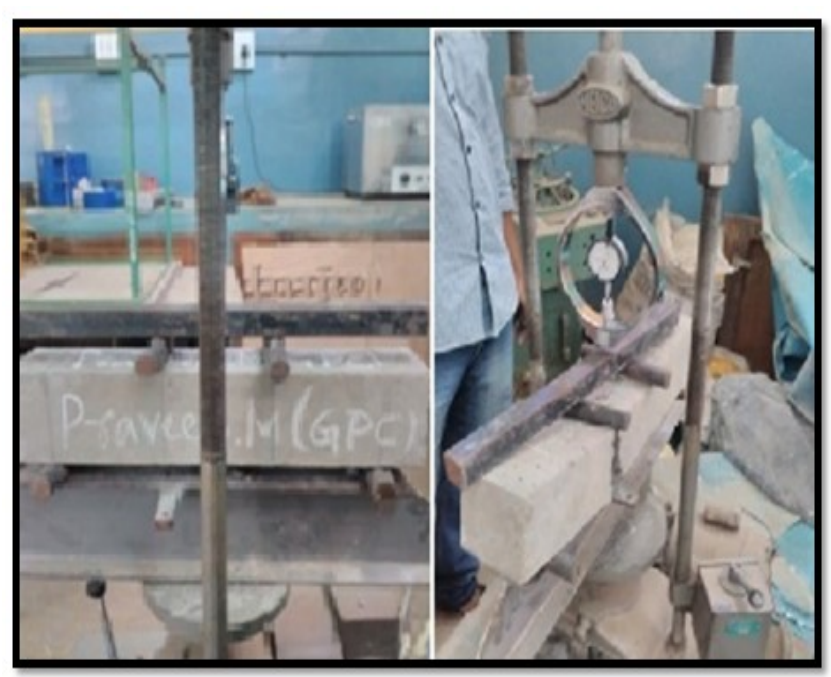

Fig -4: Flexural strength test

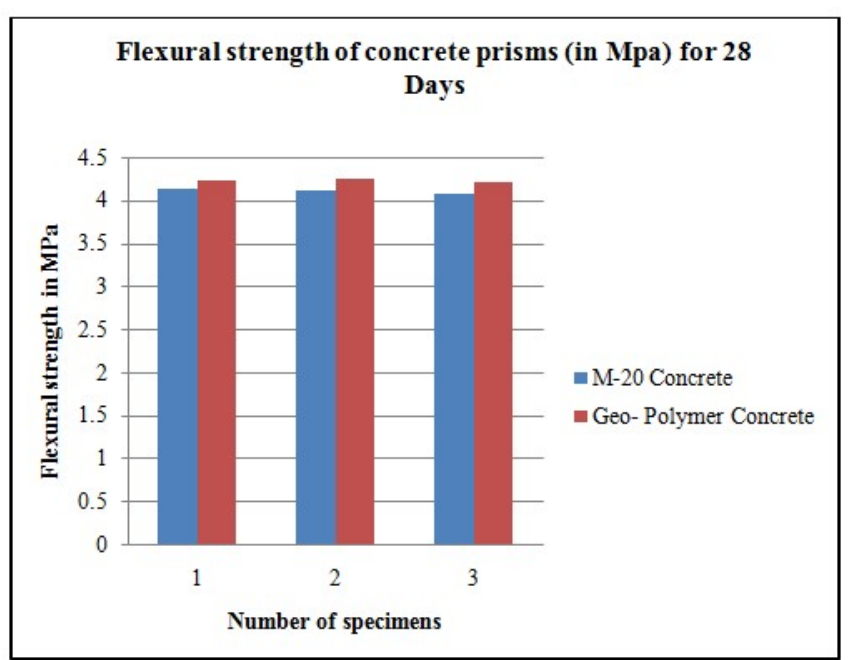

Chart -3: Flexural strength results for 7 days, 28 days.

\subsubsection{Testing of slabs}

Testing of M-20 slab and GPC slab is conducted on loading frame of 25T capacity. Slab is placed on the steel frame having dimensions of $900 \mathrm{mmX} 900 \mathrm{~mm}$, so clear cover provided to the slab is $50 \mathrm{~mm}$ on both sides. Then slab is placed on the steel frame and on this slab small I- Sections were kept, the arrangement is made as shown in the fig. 
Then loading jack is placed on it and proving ring of 25 tonnes capacity is placed and set to zero. At the bottom surface of the slab dial gauges are placed at 5 points to know the deflection of the slab.

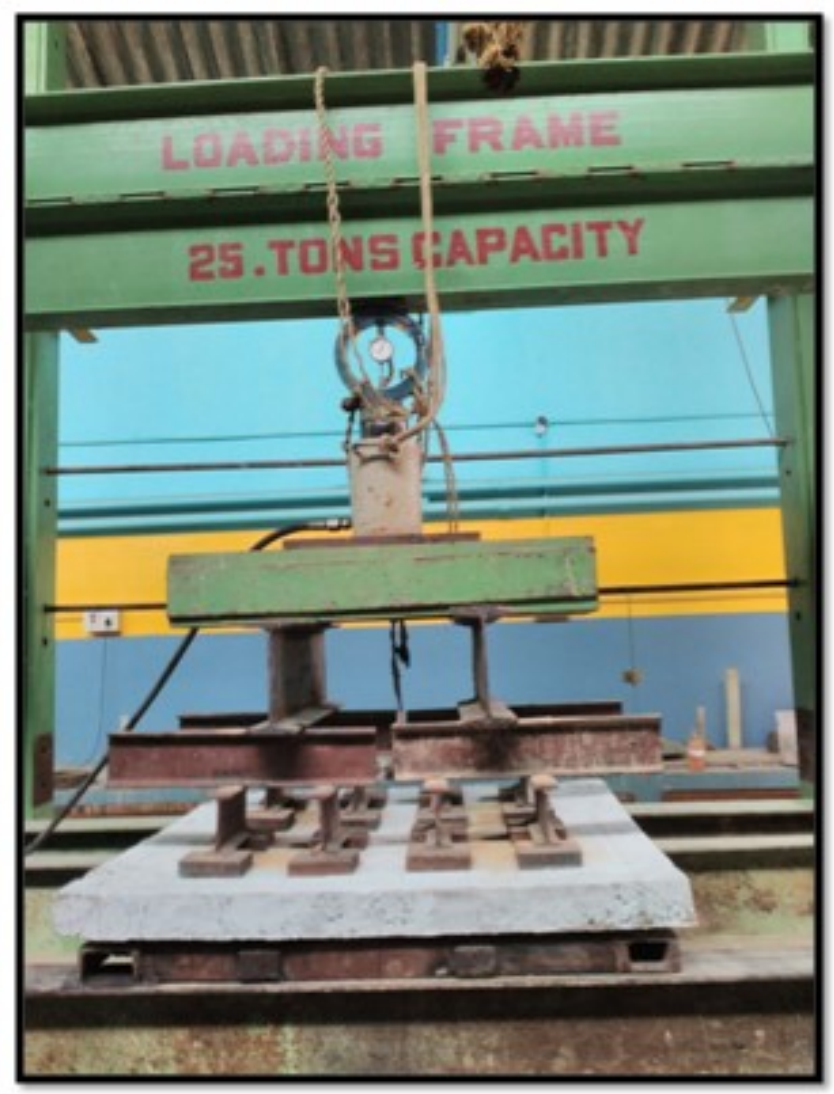

Fig -5: Testing of slabs for deflection and ultimate load

\subsubsection{Crack pattern}

Loading arrangements are as shown in the fig. then load is applied to the loading jack, deflection is measured at every $2 \mathrm{KN}$ interval. Then as the load is applied continuously the slab will goes on deflecting. At a certain load it will show crack on it that is referred as a "first crack load $\left(\mathrm{P}_{\mathrm{cr}}\right)$ ". Then loading continued diagonal cracks will appear at the centre of the slab that load is referred as a "diagonal crack load $\left(\mathrm{P}_{\mathrm{dcr}}\right)$ ". Further as loading increased the cracks get widened and the "ultimate load $\left(\mathrm{P}_{\mathrm{u}}\right)$ " taken by the slab is noted down.

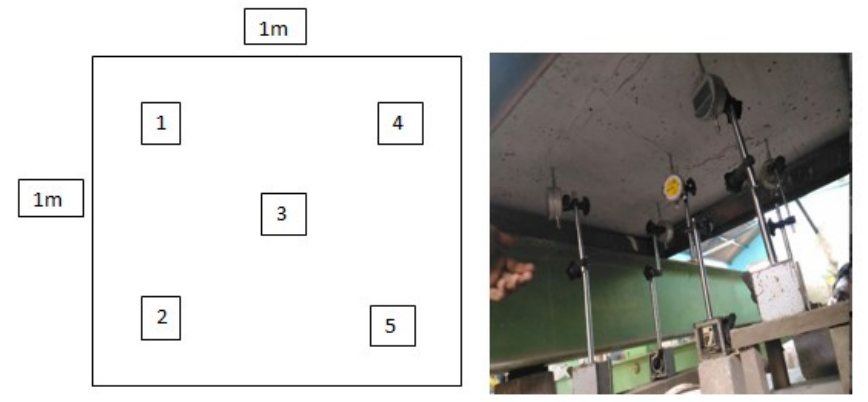

Fig -6: Deflection is measured at these 5 points and dial gauges.

\subsubsection{Test results of slab}

Table-5 Ex. of Load v/s/ deflection for OPC slab for 28 days

\begin{tabular}{|c|c|c|c|c|c|c|}
\hline \multirow{2}{*}{$\begin{array}{l}\text { Sl. } \\
\text { No. }\end{array}$} & \multirow{2}{*}{$\begin{array}{l}\text { Load } \\
(\mathrm{KN})\end{array}$} & \multicolumn{5}{|c|}{ Deflection (mm) } \\
\hline & & 1 & 2 & 3 & 4 & 5 \\
\hline 1 & 0 & 0.04 & 0.05 & 0.02 & 0.06 & 0.05 \\
\hline 2 & 2 & 0.10 & 0.10 & 0.09 & 0.09 & 0.09 \\
\hline 3 & 4 & 0.15 & 0.21 & 0.12 & 0.16 & 0.12 \\
\hline 4 & 6 & 0.33 & 0.36 & 0.36 & 0.21 & 0.19 \\
\hline 5 & 8 & 0.68 & 0.42 & 0.47 & 0.30 & 0.21 \\
\hline 6 & 10 & 0.92 & 0.50 & 0.51 & 0.37 & 0.25 \\
\hline 7 & 12 & 1.03 & 0.70 & 0.66 & 0.55 & 0.65 \\
\hline 8 & 14 & 1.24 & 0.88 & 0.85 & 0.69 & 0.81 \\
\hline 9 & 16 & 1.32 & 0.98 & 1.04 & 0.78 & 0.94 \\
\hline 10 & 18 & 1.53 & 1.12 & 1.18 & 0.91 & 1.11 \\
\hline 11 & 20 & 1.76 & 1.27 & 1.39 & 1.05 & 1.31 \\
\hline 12 & 22 & 2.01 & 1.42 & 1.54 & 1.20 & 1.52 \\
\hline 13 & 24 & 2.29 & 1.59 & 1.65 & 1.37 & 1.75 \\
\hline 14 & 26 & 2.47 & 1.70 & 1.85 & 1.49 & 1.92 \\
\hline 15 & 28 & 2.74 & 1.88 & 2.02 & 1.66 & 2.16 \\
\hline 16 & 30 & 2.93 & 2.02 & 2.37 & 1.80 & 2.34 \\
\hline 17 & 32 & 3.09 & 2.35 & 2.68 & 1.88 & 2.48 \\
\hline 18 & 34 & 3.42 & 2.51 & 2.85 & 2.16 & 2.74 \\
\hline 19 & 36 & 3.73 & 2.96 & 3.24 & 2.39 & 3.10 \\
\hline 20 & 38 & 4.29 & 3.48 & 3.46 & 2.78 & 3.21 \\
\hline 21 & 40 & 4.94 & 3.70 & 3.64 & 3.27 & 3.61 \\
\hline 22 & 42 & 5.30 & 4.00 & 4.10 & 3.57 & 4.29 \\
\hline 23 & 44 & 5.63 & 4.20 & 4.90 & 3.94 & 4.55 \\
\hline 24 & 46 & 6.03 & 4.40 & 5.40 & 4.00 & 5.02 \\
\hline 25 & 48 & 6.37 & 4.55 & 5.61 & 4.70 & 5.29 \\
\hline 26 & 50 & 6.54 & 4.60 & 6.11 & 4.73 & 5.43 \\
\hline
\end{tabular}

Table-6 Ex. of Failure loads for slab OPC for 28 days

\begin{tabular}{|c|c|}
\hline Type of load & Slab 1 \\
\hline First crack load (Pcr) in KN & 44 \\
\hline Diagonal crack (Pdcr) in KN & 70 \\
\hline Ultimate failure load (Pu) in KN & 150 \\
\hline
\end{tabular}

Similarly the load and deflection, first crack load, diagonal crack load \& Ultimate loads are noted for 3-OPC \& 3-GPC slabs are noted down. 

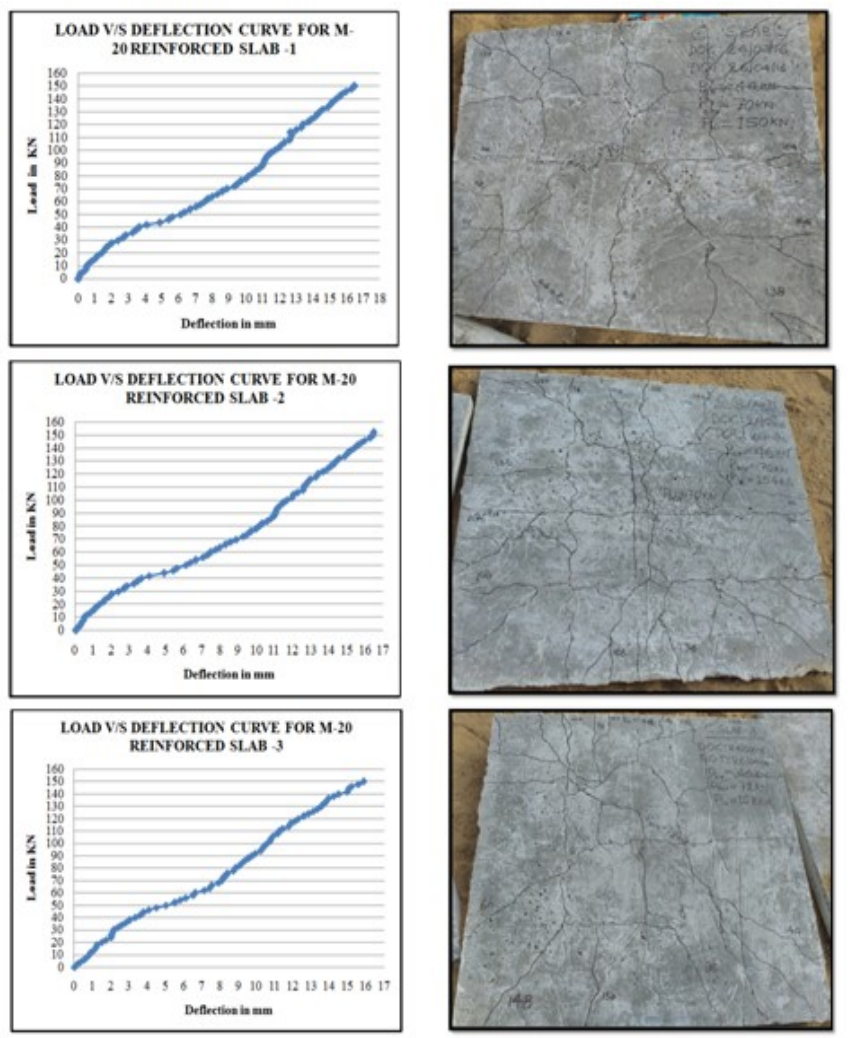

Fig -7: Load v/s deflection curve \& Crack pattern for OPC Slabs is as shown in the above fig.
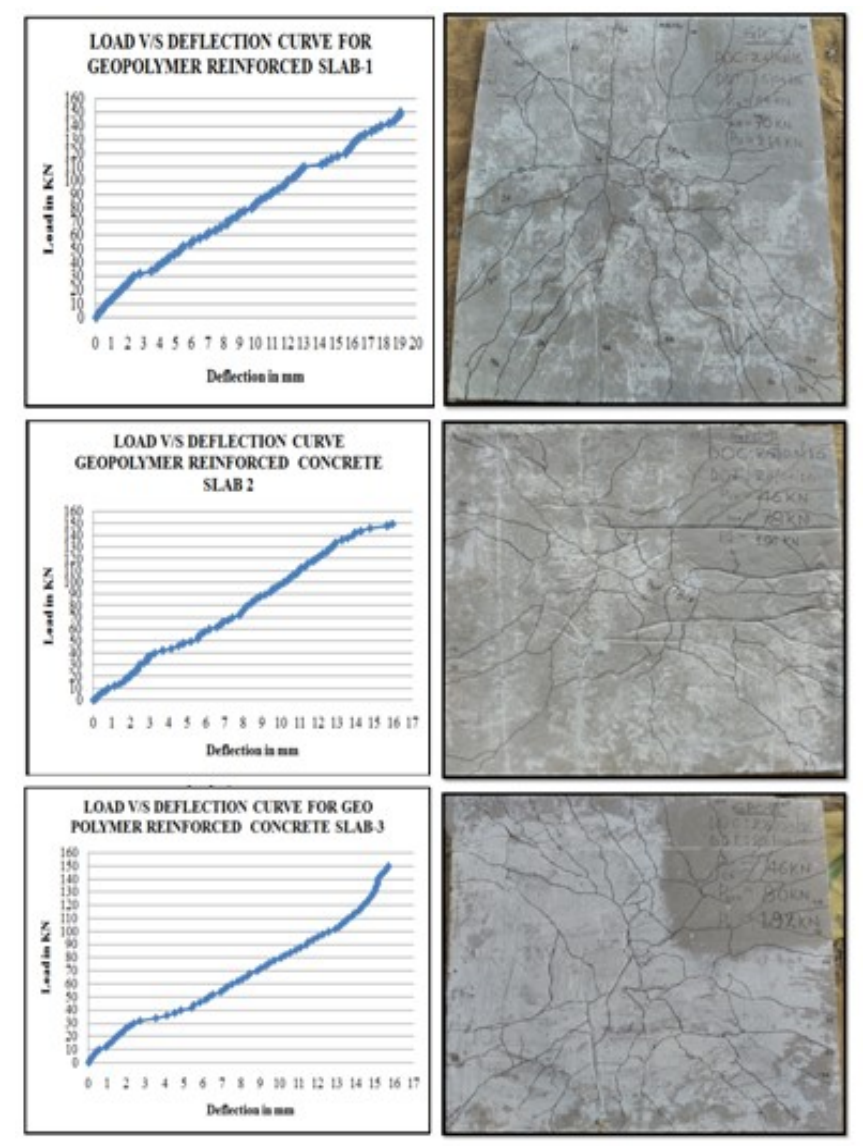

Fig -8: Load v/s deflection curve \& Crack pattern for GPC Slabs is as shown in the above fig.

\subsubsection{Overall slab test results}

Table-7 Slab test results

\begin{tabular}{|c|c|c|c|c|c|c|}
\hline \multirow{2}{*}{ Type of load } & \multicolumn{3}{|c|}{$\begin{array}{c}\text { M-20 reinforced } \\
\text { concrete slab }\end{array}$} & \multicolumn{3}{c|}{$\begin{array}{c}\text { Geo polymer } \\
\text { concrete slab }\end{array}$} \\
\cline { 2 - 7 } & $\mathbf{1}$ & $\mathbf{2}$ & $\mathbf{3}$ & $\mathbf{1}$ & $\mathbf{2}$ & $\mathbf{3}$ \\
\hline$\left(\mathrm{P}_{\mathrm{cr}}\right)$ in $\mathrm{KN}$ & $\mathbf{4 4}$ & $\mathbf{4 6}$ & $\mathbf{4 4}$ & $\mathbf{4 6}$ & $\mathbf{4 6}$ & $\mathbf{4 6}$ \\
\hline$\left(\mathrm{P}_{\mathrm{dcr}}\right)$ in $\mathrm{KN}$ & $\mathbf{7 0}$ & $\mathbf{7 0}$ & $\mathbf{7 2}$ & $\mathbf{7 6}$ & $\mathbf{7 8}$ & $\mathbf{8 0}$ \\
\hline$\left(\mathrm{P}_{\mathrm{u}}\right)$ in $\mathrm{KN}$ & $\mathbf{1 5 0}$ & $\mathbf{1 5 4}$ & $\mathbf{1 5 2}$ & $\mathbf{2 1 4}$ & $\mathbf{1 9 0}$ & $\mathbf{1 9 2}$ \\
\hline
\end{tabular}

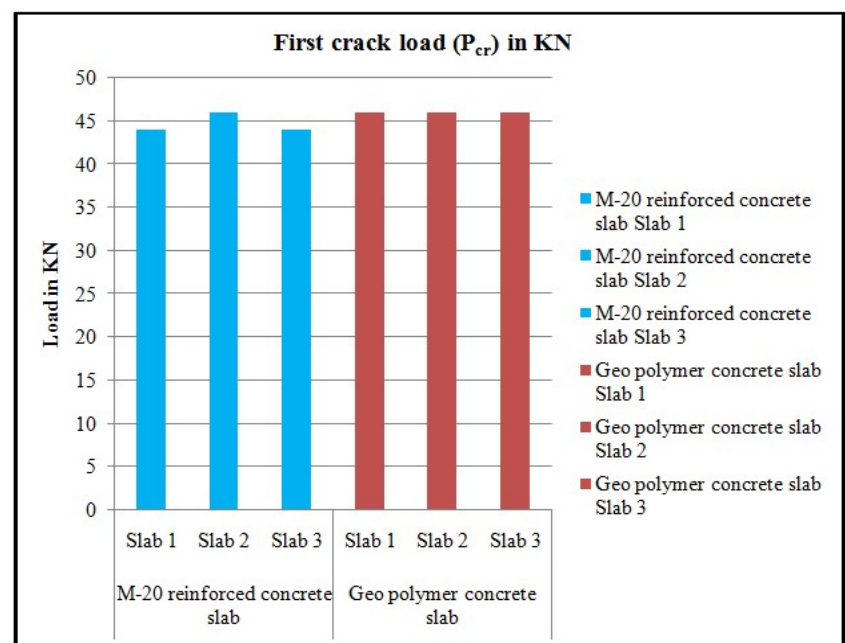

Chart -4: First crack load (Pcr) in KN

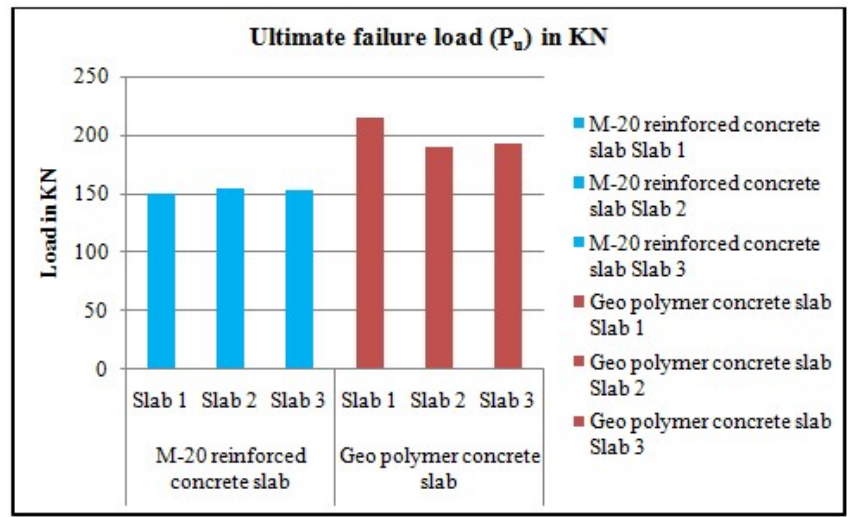

Chart -5: Ultimate failure load $(\mathrm{Pu})$ in $\mathrm{KN}$

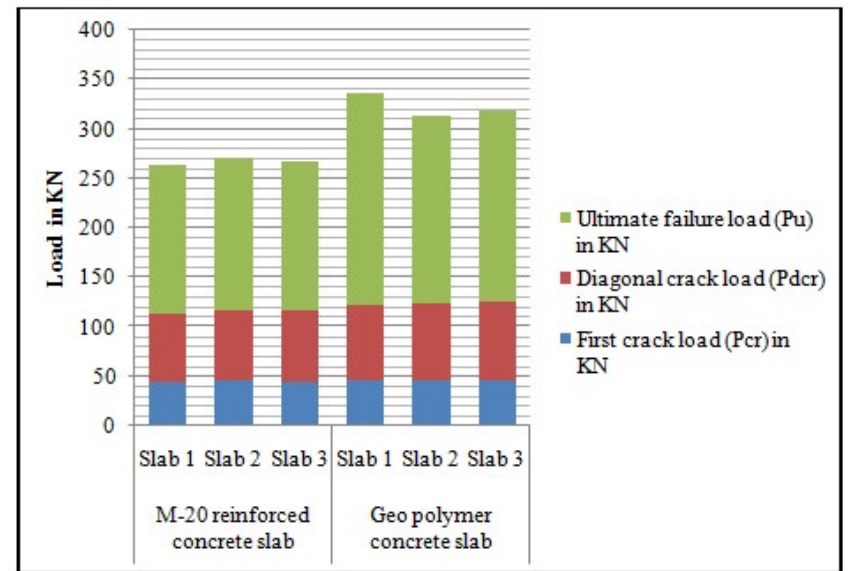

Chart -6: Graphical representation of the first crack, diagonal and ultimate failure loads for slabs. 


\subsection{CONCLUSIONS}

1. Compressive strength of the geo polymer concrete (GPC) for 7 days is increased by $58.73 \%$ when compared with the M-20 concrete. And 7 day compressive strength of geo polymer concrete is of $44.15 \mathrm{~N} / \mathrm{mm}^{2}$. For 28 days the compressive strength of GPC obtained is of $63.71 \mathrm{~N} / \mathrm{mm}^{2}$ and the percentage increase in strength observed is $42.80 \%$. Compressive strength of GPC for 56 days is found to $70.22 \mathrm{~N} / \mathrm{mm}^{2}$ and percentage increase in the strength is $42.80 \%$ when compared to M-20 concrete.

2. The split tensile strength of GPC for 7 days is $37.05 \%$ more than that of the M-20 concrete. And for 28 days it is $30.80 \%$ more than that of $\mathrm{M}-20$ concrete.

3. Flexural strength of GPC for 28 days is $2.80 \%$ more than that of M-20 concrete.

4. The first crack load for the GPC is quite more than the M-20 reinforced ordinary portland cement slab. First crack load observed for GPC at $46 \mathrm{KN}$

5. The diagonal cracks developed load in case of the GPC is higher than M-20 concrete i.e. for GPC it was $78 \mathrm{KN}$ and for concrete it was $70 \mathrm{KN}$

6. The ultimate load carrying capacity for GPC slab is more than the M-20 OPC slabs. GPC slabs will resist higher loads up to $196 \mathrm{KN}$ and for M-20 OPC slabs it is of $152 \mathrm{KN}$.

7. Failure patterns for GPC slabs shows localized failure i.e. failure of the slab at the centre, similar failure patterns were observed for M-20 OPC slabs.

8. It can be concluded that geo polymer concrete slabs can be used as a structural members.

9. From the above statements it can be concluded that the geo polymer concrete is more suitable for early strength gain development works. Ex: this is more suitable for road repair works or any other type of patch works.

\section{SCOPE FOR FURTHER WORK}

1. This research work can be extended for the varying thickness of the slab.

2. The experiment can be carried for varying percentage of the flyash and GGBS.

3. Shrinkage characteristics of the geo polymer concrete can be studied.

4. The study can be made for the different curing periods at various temperatures.

5. The behavior of geo polymer concrete at elevated temperature can be studied.

\section{ACKNOWLEDGMENT}

I wish to express my profound gratitude and indebtedness to my guid Prof. Ramesh Babu B I T, Bengaluru, for their inspiring guidance, and valuable suggestion throughout this project work.

I have a great pleasure to express my deep sense of gratitude towards HOD Dr. Aswath M.U. for his sterling efforts amenable assistance and inspiration in all phases of my project work.
I wish to express my sincere thanks to RMC-HIGHTECH, RMC-INDIA \& Dr.Devaraj KIMS Bengaluru, for providing the flyash, GGBS \& reinforcement for completion of this project.

\section{REFERENCES}

[1] T Kiran, Sadath Ali Khan, Srikant Reddy S (2015), "Impact test on geo polymer concrete slabs", International Journal of Research in Engineering and Technology, Volume: 04, Issue: 12, pp 110-116.

[2] Dr.Manjunatha N Hegde, Sandeep S, T. Chandrasekaraiah (2014) "The strength and durability properties of the lightly reinforced geo polymer concrete slabs subjected to the different time period of accelerated carbonation", International Journal of Advancement in Engineering Technology, Management and Applied Science, Volume 1, Issue 2, July 2014, pp 80-90.

[3] Madheswaran C K, et. al (2014) "Investigation on behaviour of reinforced geopolymer concrete slab under repeated low velocity impact loading", International Journal of Innovative Research in Science, Engineering and Technology, Volume: 03, Issue: 3, pp 1077510786.

[4] Dr. Amarnath K, et. al (2015) "Study on flexural behavior of flyash based reinforced rectangular geo polymer concrete slab", International Journal of Engineering Research and Technology, Volume: 04, Issue: 09, pp 523-528.

[5] IS 456 - 2000 "plain and reinforcement concrete code of practice", Indian standard Bureau, New Delhi, India.

[6] IS 516-1959:-Method of test for strength of concrete.

[7] Rajamane N.P, Jeyalakshmi R (2015) "Quantities of sodium hydroxide solids and water to prepare sodium solution for a given molarity for geo polymer concrete mixes".The Indian Concrete Institute (ICI) Technical paper, Aug- Sep 2014, pp 04-09.

\section{BIOGRAPHIES}

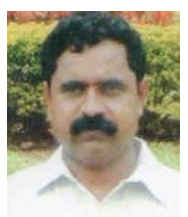

Ramesh Babu B.E., M.Tech, Assistant Professor, Bangalore Institute of Technology, has 29 years of experience in teaching \& industry. His research areas include study on the properties of alkali activated flyash (geo polymer) concrete. He is actively involved in guiding M.Tech thesis \& industry related consulties.

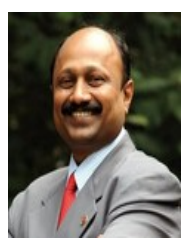

Dr.Aswath M U M.Tech, Ph.D.Prof. \& HOD of Civil dept. BIT, has 20 years of professional experience in structural designer $\&$ project management. Guiding 5 students for Ph.D. \& 18 students for M.Tech. Published more than 50 papers in national \& international journals / conferences.

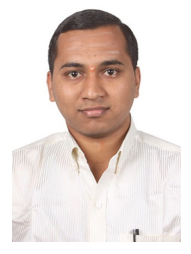

Praveen Mathapati B.E. is pursuing M.Tech (Structural Engg.) at Bangalore Institute of Technology. In Bachelor of Engineering (Civil) secured 9th rank to VTU. Now presently working as Assistant Engineer in Rural Development \& Panchayat Raj Department. 